\title{
ВЛИЯНИЕ РАЗВИВАЮЩЕЙ ПРЕДМЕТНО-ПРОСТРАНСТВЕННОЙ СРЕДЫ НА ФОРМИРОВАНИЕ КОММУНИКАТИВНЫХ НАВЫКОВ В ПРОЦЕССЕ ДИДАКТИЧЕСКИХ ИГР У СТАРШИХ ДОШКОЛЬНИКОВ
}

\author{
Клезович Ирина Ивановна \\ воспитатель \\ ГБОУ Школа №851, г. Москва
}

Аннотация: В статье раскрываются особенности построения общения в дошкольном возрасте, дается определение коммуникативных навыков разных исследователей, на основе которых автор выделяет общее.

Изучены особенности развития общения и формирования коммуникативных навыков в период старшего дошкольного возраста посредством дидактических игр. В статье акцентируется внимание на основных шагах, которые позволят обеспечивать развитие коммуникативных навыков у дошкольников в процессе проведения с ними дидактических игр в рамках развивающей предметно-пространственной среды.

Ключевые слова: Коммуникативные навыки, развивающая предметнопространственная среда, дидактическая игра, социализация, социальное развитие.

\section{INFLUENCE OF THE DEVELOPING SUBJECT-SPATIAL ENVIRONMENT ON THE FORMATION OF COMMUNICATION SKILLS IN THE PROCESS OF DIDACTIC GAMES IN OLDER PRESCHOOLERS}

\section{Klezovich Irina Ivanovna}

Abstract: The article reveals the features of building communication in preschool age, defines the communication skills of different researchers, on the basis of which the author identifies the general.

The features of the development of communication and the formation of communication skills in the period of senior preschool age through didactic games are studied. The article focuses on the main steps that will ensure the development of communication skills in preschoolers in the process of conducting didactic games with them within the developing subject-spatial environment. 
Key words: Communication skills, developing subject-spatial environment, didactic game, socialization, social development.

Одной из важных задач дошкольного воспитания заключается в развитии у детей способностей положительного общения со сверстниками и взрослыми. Общение между детьми является необходимым условием для психического развития личности. А потребность в общении с раннего возраста становится основной социальной потребностью ребенка. При этом, общение детей со сверстниками имеет важное значение для развития личности дошкольника. При этом характеризуется отличительными особенностями по своим функциям и проявлению.

Важное значение и актуальность имеет изучение развития детей в системе построения межличностного общения со сверстниками, особенно в период дошкольного возраста, поскольку он представляет собой один из ответственных периодов воспитания ребенка. Этот период является временем для первоначального становления личности детей, наряду с этим в общении ребенка со сверстниками появляются довольно сложные взаимоотношения, которые оказывают существенное влияние на развитие личности.

Все это способствует тому, что от педагога требуется организация учебно-воспитательного процесса таким образом, чтобы развитие каждого дошкольника было не только интеллектуальным, но и способствовало полноценному развитию коммуникативных навыков.

Коммуникативные навыки помогают формировать социальную компетентность, учитывая позицию партнера по общению или деятельности. Они направлены на обучение умению слушать и вести беседу, решать коллективные вопросы, интегрироваться в группе сверстников и т.п.

C.С. Бычкова классифицирует коммуникативные навыки с позиций теории речевой деятельности. Она разделяет навыки, обеспечивающие речевую деятельность, на навыки, необходимые для создания высказываний (для говорения и письма), и на навыки, необходимые для восприятия высказываний (для слушания и чтения). Таким образом, в основе данной классификации лежат виды речевой деятельности [2].

По свидетельству Л.С. Выготского, М.И. Лисиной, Т.А. Репиной и др., активное развитие у старших дошкольников способности к позитивному и разнообразному общению обеспечивает им успешную социализацию, смену 
социальных ролей, познание окружающего мира, в том числе других людей, и самопознание [4].

При этом, развитие коммуникативных навыков невозможно без организации групповой работы, ведь, взаимодействуя со сверстниками, дети овладевают языком и речью как средствами общения, познания, самоутверждения в жизни, могут продемонстрировать свои творческие способности. Поэтому чрезвычайно важно на каждом занятии привлекать детей к групповой и игровой деятельности. Коммуникативные навыки помогают формировать социальную компетентность, учитывая позицию партнера по общению или деятельности. Они направлены на обучение умению слушать и вести беседу, решать коллективные вопросы, интегрироваться в группе сверстников и т.П. [1].

На сегодня эффективным выступает использование инновационного подхода к организации предметно-развивающей среды в ДОУ для формирования коммуникативной компетенции дошкольников.

Коммуникативная компетенция выступает как совокупность действий, обеспечивающих социализацию ребенка, его сознательную ориентацию на позицию другого человека, партнеров по деятельности или общению, умение слушать и вступать в диалог, участвовать в обсуждении тех или иных проблем, эффективно адаптироваться в группе сверстников и строить взаимодействий и сотрудничество со взрослыми.

Развитие коммуникативных навыков связано с приобретением ребенком умений устанавливать контакт с партнером в общении, соблюдая правила этикета. Ребенок наблюдает и следует примерам общения взрослых, детей между собой. Однако педагог не всегда готов к созданию речевой развивающей среды, а деятельность дошкольника обычно сводится к выполнению им ряда воспитательных задач. Поэтому, по нашему мнению, с целью формирования коммуникативной компетенции у дошкольников важно создать благоприятный климат на занятиях с использованием предметно-развивающей среды, которые будут помогать учиться в непринужденной атмосфере творческого сотрудничества, положительных эмоций, самовыражения, свободного выражения мнений.

Поэтому, по нашему мнению, с целью формирования коммуникативных навыков у дошкольников важно создать благоприятный климат на занятиях с использованием дидактических игр, которые будут помогать учиться в 
непринужденной атмосфере творческого сотрудничества, положительных эмоций, самовыражения, свободного выражения мнений.

Игра является одним из самых интересных видов человеческой деятельности, ведущей деятельностью дошкольника, а также средством его всестороннего развития и важным методом воспитания.

Одним из видов игровой деятельности является дидактическая игра, которая позволяет приобщать ребенка к текущей жизни в доступной форме интеллектуально и активной практической деятельности. Главной задачей дидактических игры является обеспечение благоприятных условий для решения педагогических задач, учитывая возможности детей дошкольного возраста [3].

Дидактические игры повышают эффективность восприятия дошкольниками учебного материала, разнообразят их деятельность, вносят в нее элемент любопытства. Дидактическая игра используется как средство создания благоприятной среды для общения, что необходимо для формирования коммуникативных навыков. Их использование повышает интерес к деятельности, позволяет сконцентрировать внимание на овладении речевыми навыками в процессе естественной ситуации общения.

Ценность дидактических игр заключается в том, что дети самостоятельно приобретают новые знания, активно помогают друг другу в этом. Дидактическая игра также повышает качество воспитания, поскольку играя, дошкольники вынуждены использовать свой запас знаний, умений и навыков, так как игровая ситуация переживается ими как реальная.

Игры способствует развитию внимания у детей, поскольку победа в ней связана с наблюдениями за речью и действиями игроков, которые часто непредсказуемы, а это в свою очередь требует быстрой и адекватной реакции. Кроме того, приподнятое настроение и положительные эмоции способствуют более быстрому запоминанию игры по развитию речи. Используя дидактические игры, педагог развивает интерес к языку, сосредоточивает внимание детей, привлекая их к активной работе. Дидактическая игра помогает сделать процесс повторения лексики и грамматических конструкций захватывающим для дошкольников.

Использование игр как средства развития коммуникативной функции речи дошкольников позволяет педагогу ставить перед детьми задачи, в которых есть мотив и цель речевого действия и которые диктуют использование необходимых образцов общения. 
В зависимости от темы и цели занятия могут быть использованы дидактические игры, как для представления нового материала, для его закрепления и активизации в речи детей, во время релаксации или для проверки усвоения материала. Дидактические игры применяются как отдельные элементы занятия или все занятие может быть проведено в форме игры с элементами соревнования между группами.

При этом современные условия требуют инновационного подхода в создании предметно-пространственной среды помещений групп, которые выступают как пространство жизнедеятельности детей, обеспечивающее максимальные возможности развития детского творчества, экспериментирования и исследовательского интереса каждого ребенка. Для чего и необходимо составление целостного дизайн-проекта дошкольной образовательной организации.

Предлагаем выделить последовательность действий для создания развивающей предметной среды в группе дошкольной образовательной организации на основе восьми шагов, которая будет обеспечивать развитие коммуникативных навыков у дошкольников.

1. Важно формулировать цели и задачи, которые позволят определить приоритетное направление в развитии дошкольников. На этой основе подбирать предметы в пространственно-развивающую среду группы.

2. Определить набор необходимых учебных и методических пособий, которые будут способствовать формированию коммуникативных навыков детей, подобрать игрушки и ряд материалов для самостоятельной детской деятельности.

3. Составить перечень необходимого дополнительного оборудования, которое будет предназначено для хранения выбранного игрового и познавательного материала, обеспечивать доступ детей к игрушкам и дидактическим материалам.

4. Определить пространственное размещение выбранных пособий, игрушек и другого материала, основываясь на принципах центров активности.

5. Провести диагностику, которая будет направлена на изучение уровня сформированности коммуникативных навыков дошкольников, уровня их развития, на основе которой будет определяться наполняемость предметнопространственной развивающей среды.

6. Продумать последовательность работы с детьми, опираясь на имеющиеся материалы, а также разработать план приобретения новых 
материалов и оборудования, которые понадобятся в работе с детьми по мере развития у них коммуникативных навыков.

Таким образом, в первую очередь, предметно-пространственная развивающая среда должна включать необходимые и достаточные предметы и оборудование, т. е. должна быть максимально насыщенной, и обеспечивать каждый вид детской деятельности. В то же время, все материалы должны подбираться с учетом возраста детей в конкретной группе и соответствовать возрастной специфике каждого вида деятельности.

В связи с этими критериями воспитатели и специалисты должны:

- знать требования, которые выдвигаются к качеству игровых средств и уметь выбирать игры, игрушки и оборудование с большим развивающим потенциалом, соответствующие требованиям современных стандартов воспитания;

- иметь четкое представление о степени оснащенности предметнопространственной среды группы и других помещений детского сада, уметь видеть недостатки, нехватку одних и превалирование других предметов и оборудования, выделять главные и второстепенные предметы;

- быть мотивированными и нацеленными на оснащение среды современными игровыми средствами, взаимодействовать с родителями дошкольников по наполнению предметно-развивающей среды группы;

- уметь применять игровые средства, для решения образовательных, воспитывающих и развивающих задач в различных образовательных областях знаний [1].

Таким образом, инновационная развивающая предметнопространственная среда должна стимулировать творческие способности, служить интересам и потребностям ребенка, обогащая развитие специфических видов деятельности, обеспечивать зону ближайшего развития ребенка, побуждать к осознанному выбору, уметь принимать самостоятельные решения, выдвигать и реализовывать собственные инициативы, а также формировать личностные качества дошкольников и их жизненный опыт. Создавая развивающую предметно-пространственную среду в дошкольном учреждении, которая будет направлена на формирование коммуникативных навыков детей дошкольного возраста, необходимо учитывать психологические основы продуктивного взаимодействия всех участников образовательного и воспитательного процесса, эргономику и дизайн современной среды 
дошкольного учреждения, и психологические особенности возрастной группы, на которую нацелена данная среда.

\section{Список литературы}

1. Бетанова С.С., Сухова А.А. Предметно-развивающая среда в дошкольном образовании // StudNet. 2020. №3.

2. Бычкова С.С. Формирование умения общения со сверстниками у старших дошкольников. Метод. Рекомендации. - М.: АРКТИ, 2016 - 96 с.

3. Хафизова К.А. Особенности формирования коммуникативной компетенции старших дошкольников // Интерактивная наука. 2019. №6 (40).

4. Отношения между сверстниками в группе детского сада: (Опыт соц.психол. исслед.) / под ред. Т. А.Репиной. - М. : Педагогика, 2018. -200 с. 